\title{
Election 2015: Vote for public health, says CPHA
}

$\mathrm{B}$ efore voting on Oct. 19, the Canadian Public Health Association (CPHA) is encouraging its members to review the parties' election platforms through a public health lens.

The CPHA is highlighting five critical issues for its 1200 individual and organizational members: basic income guarantees; a national strategy on early childhood education; a less punitive approach to illicit drugs; an inquiry into missing and murdered Aboriginal women; and stronger action on climate change.

Polls continue to indicate health, and improving public health, are top issues for Canadians. But neither health care delivery nor securing public health have received the attention they deserve during the campaign, says Ian Culbert, CPHA executive director.

"While some of the parties deal with the question of health care or funding for health care, they really don't take a serious look at some of the broader issues that are important to Canadians," Culbert says. "These are complex issues that need well-rounded conversations and discussions to be able to forge an appropriate plan for the future."

The CPHA election guide encourages its members to get involved and ask tough questions during the campaign, through social networking, letters, town hall sessions and by engaging individual candidates. "We should not be satisfied with rehearsed answers that lack depth. We need to hold the candidates themselves to a higher standard and expect more from them," the CPHA election material urges.

The five priorities aim to achieve concrete results such as: equitable access to quality childcare; restricting access to fentanyl; repealing the Respect for Communities Act to make it easier to create more supervised injection sites; and adopting a "public health approach" to cannabis, as well as enshrining the right to a healthy environment in the Charter of Rights and Freedoms.

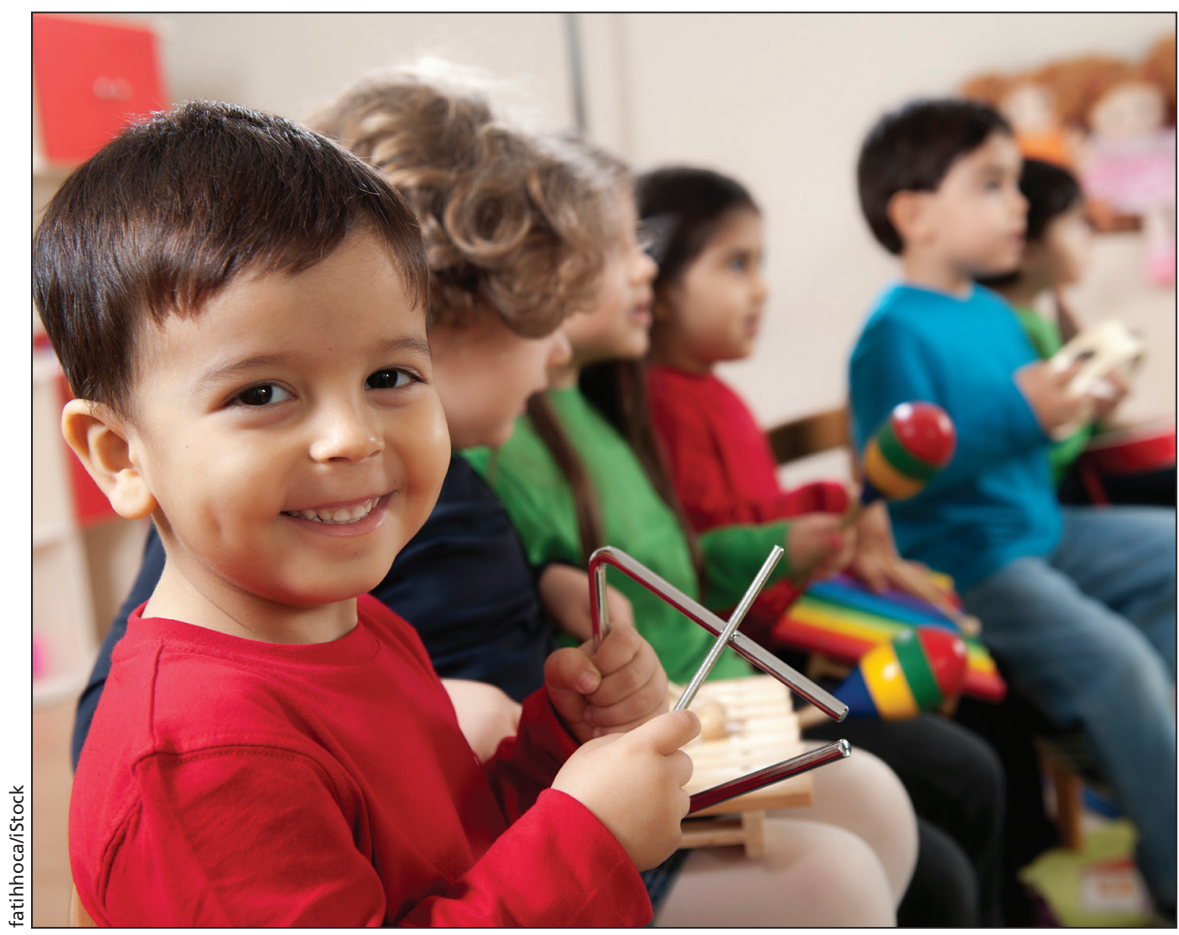

The Canadian Public Health Association urges voters to assess parties' policies on public health, which should include a national strategy on early childhood education.

The CPHA does not have the resources to track whether its members are actively involved in the election campaign, says Culbert. The campaign guide has received a positive response, he adds.

Raising these issues is important in "the current environment," in which commitment to national strategies that promote prevention and healthy populations, and to a robust Public Health Agency of Canada, have been "whittled down or watered away," Culbert adds.

A November 2014 editorial in the Canadian Journal of Public Health accused both the federal government and several provinces of trying to weaken public health and diminish their roles in advocating for a fairer distribution of societal resources and improved living conditions.

Public health advocates have pointed to numerous examples of this weakening, including cuts to the federal health program for refugees, which Conservative Leader Stephen Harper said during the Sept. 17 leadership debate only affected "clearly bogus refugees." They also continue to cite the elimination of the compulsory long-form census, Canada's best source of information on regional health disparities. The Conservatives said there were privacy concerns with the long-form and replaced it with a voluntary National Household Survey.

Culbert has identified a national leadership gap in strategies around Hepatitis C, e-cigarettes, sodium, immunization and suicide prevention. "There's a huge leadership role that the federal government has to play in bringing the provinces and territories along in creating national strategies."

Dr. Trevor Hancock, a professor and senior scholar at the University of Victoria's School of Public Health and Social Policy, says a strong public health agenda would also include national strategies to prevent chronic diseases; a food policy geared towards healthy eating and ecologically sustain- 
able agriculture; and an independent Public Health Agency of Canada.

In a recent column Hancock wrote for the Victoria Times-Colonist, he pondered what the election campaign would be like if public health took centre stage.

"Right now, to listen to the campaign, you'd think that Canada's [only] business was to grow the economy and ensure security," Hancock told CMAJ. If health mattered in this election, the next federal government would adopt a population health policy and appoint a Cabinet committee to oversee it, he added.

"We need to switch the conversation to one that talks about 'how do we maximize human well-being within the limits of the single small planet we live on and share with a lot of other people and a lot of other species?" - Laura Eggertson, Ottawa, Ont.

CMAJ 2015. DOI:10.1503/cmaj.109-5177 